\title{
Nucleic acid testing of hepatitis $B$ virus, hepatitis $C$ virus, and human immunodeficiency virus 1, 2 in blood donors in the General University Hospital, Prague
}

\author{
D. DUŠKOVÁ, L. DAREBNÍČEK
}

General University Hospital in Prague, Faculty Transfusion Department, U Nemocnice 2, 128 08, Prague 2, Czech Republic

Received May 21, 2013; accepted May 19, 2014

\begin{abstract}
Summary. - The Roche Cobas TaqScreen MPX Test v1 - multiplex reverse transcription-real time (MPX RT-Real Time) PCR, performed on Cobas s201 for HCV RNA, HBV DNA, HIV-1 RNA /group M and O/, and HIV-2 RNA was introduced as a supplement to the currently used imunoanalysis method for blood donor's testing (Abbott CMIA - chemiluminescent microparticle imunoassay, performed on Architect i2000 for antiHCV, hepatitis B surface antigen (HBsAg), anti-HIV-1 /group M and O/, anti-HIV-2 and p24 HIV). The results of study could provide valuable arguments to support the discussion about the NAT implementation into the standards of blood donor's testing in the Czech Republic. Two groups of samples were tested. In the first one, 5074 samples from consecutive blood donors, and in the second one, 5 repository preseroconverted samples from repeat blood donors, who were subsequently confirmed positive for Viral Hepatitis and/or HIV/AIDS by the National Reference Laboratory (NRL), were tested. One sample was found reactive by chemiluminescent microparticle immuno assay (CMIA) and nucleic acid test (NAT) (confirmed HBV-positive in NRL), 31 samples were CMIA-only reactive (15 anti-HCV, $4 \mathrm{HBsAg}, 12$ anti-HIV/p24, all confirmed negative in NRL) and one pool (6 samples) was found reactive (further individual NAT was negative for all samples) in the first group of samples. One sample was NAT-only reactive (confirmed HCV-positive in NRL) in the second group of samples. Our study confirmed that screening of infectious markers using NAT can reduce the risk of transmitting the monitored infections by blood transfusion in the Czech Republic, even as a country with currently good epidemiological situation.
\end{abstract}

Keywords: HBV; HCV; HIV; blood donors testing; CMIA; NAT

\section{Introduction}

Despite today's advanced knowledge of medicine and new modern technologies, one of the transfusion medicine's main risks remains transfusion transmitted infection (TTI).

E-mail: Duskova.Daniela@vfn.cz; phone: +420-225374271. Abbreviations: CMIA = chemiluminescent microparticle immuno assay; FTO VFN = Faculty Transfusion Department of the General University Hospital in Prague; HBV = hepatitis B virus; $\mathrm{HCV}=$ hepatitis $\mathrm{C}$ virus; HIV-1,2 = human immunodeficiency virus 1 and 2; NAT = nucleic acid test; NRL = National Reference Laboratory for Viral Hepatitis in Prague and/or for AIDS; MPX RT-Real Time PCR = multiplex reverse-transcription-real time PCR; $\mathrm{S} / \mathrm{CO}=$ signal/cutt-off value; TTI = transfusion transmitted infection
Transfusion departments try to reduce this risk during the process of selecting suitable blood donors through establishing general principles of donor selection and guidelines for deferral, by using processes of blood component preparation that reduce the possibility of exogenous bacterial contamination, and also by screening for clinically important markers of infectious diseases in blood donors.

No agreement has been reached, either in Europe or worldwide, concerning the mandatory methods and obligatory tested infectious markers in blood donors. A worldwide agreement is only in place for selection of three clinically important infections to be tested in blood donors - markers of HIV-1,2, HBV, and HCV. Some countries also perform screening for other infectious markers (i.e. hepatitis A virus, Malaria, HTLV I/II, parvovirus B19, 
West Nile Virus) based on their particular epidemiological situation (McCullough, 2005).

The minimal requirement for screening of infectious markers in blood donors in the European Union (EU Directive 2002/98/ES) is to test for the presence of antibodies to HIV-1 and HIV-2, antibodies to HCV virus and HBsAg. The infectious markers that are tested beyond the European Union Directive in the Czech Republic detect p24 antigen of HIV and antibody to Treponema pallidum (Regulation about human blood No. 351/2010).

The aim of this study was to provide a proof of the reduction of TTI risk by identifying NAT-positive donors before their seroconversion, while applying NAT (Roche TaqScreen MPX, v1) for screening of HCV RNA, HBV DNA, HIV-1 RNA (group $\mathrm{M}$ and $\mathrm{O}$ ), and HIV-2 RNA. Our standard blood donors population was initially tested using serological methods - magnetic particle-based chemiluminescent enzyme immunoassay (Abbott CMIA). No such study has been performed in the Czech Republic till 2009. The data obtained during the study could therefore help to create an algorithm for future screening of infectious markers in blood donors using the combination of standard serological methods and NAT.

\section{Materials and Methods}

Selection of samples. The first group of samples (Group 1; 5,074 samples from consecutive blood donations) closely reflected the pattern of the blood donors population in the Faculty Transfusion Department of the General University Hospital in Prague (FTO VFN), i.e. samples obtained from different types of donation (whole blood, plasmapheresis), different types of blood donors (first time blood donors, repeat blood donors) and different regions (Prague, subcentres Jihlava and Chrudim, Table 1). These samples were obtained during four consecutive months in 2008.
Due to a low prevalence of monitored infections in the general population of the Czech Republic (Němeček et al., 2011; NRL; database of FTO VFN) and based on the number of samples in the Group 1, we decided to select an additional group of samples for testing. In the additional group of samples (Group 2) we tested only Abbott CMIA negative repository samples (archived between April 2004 and February 2010) from donors with following sample Abbott CMIA reactive and confirmed positive in the National Reference Laboratory for Viral Hepatitis in Prague and/or for AIDS (NRL). From the total of 150,000 repository samples, we finally selected five repository preseroconverted samples, all of them were from male plasmapheresis donors, 3 samples (60\%) from subcentres donors, 2 samples (40\%) from Prague donors. Most of the donors were confirmed HCV-positive by NRL (4 donors, $80 \%$ ) following donation, others were HBV-positive as confirmed by NRL (20\%). The donation interval (preseroconverted sample - seroconverted sample) was 4.4 months on average (ranging between 3 to 8 months).

Sample testing. All samples in both groups were tested by Abbott CMIA and Roche Cobas TaqScreen MPX Test v1, the tested material was plasma (Table 2).

Abbott CMIA. A routine immunoassay for the screening of infectious markers in FTO VFN is performed using the Abbott Architect i2000 system (Abbott, Wiesbaden, Germany). Antibody anti-HCV, HBsAg, anti-HIV-1 (group M and O), antibody antiHIV-2 and p24 antigen HIV were tested. The chemiluminescent detection of anti-HCV and anti-HIV/p24 was qualitative, detection of $\mathrm{HBV}$ was quantitative, the products of the reaction were separated by a magnetic microparticles. Signal/cut off value (S/ $\mathrm{CO}$ ) including greyzone for positive results was $\geq 0.80$ (HBV, $\mathrm{HCV}$ ) and $\geq 0.85$ (HIV). One positive and one negative internal control for each marker (3 level positive control for HIV) as well as another positive/negative external control for each marker were included.

Roche Cobas TaqScreen MPX Test v1. The molecular-biological assay with fluorescent detection of target DNA in real time uses reverse transcription for the detection of RNA (Real Time RT- PCR). This method was performed for the screening for HCV RNA, HBV DNA,

Table 1. Group 1 of tested samples - summary (Database of FTO VFN)

\begin{tabular}{|c|c|c|c|c|c|c|}
\hline \multirow{2}{*}{ Total amount of samples } & \multicolumn{6}{|c|}{5074} \\
\hline & Number & Males & & Females & (\% Males) & (\% Females) \\
\hline Plasmapheresis (FTO VFN) & 821 & 649 & & 172 & 79.05 & 20.95 \\
\hline Whole blood (FTO VFN) & 1113 & 698 & & 415 & 62.71 & 37.29 \\
\hline Whole blood (Subcentres) & 3140 & 2103 & & 1037 & 66.97 & 33.03 \\
\hline \multirow[t]{2}{*}{ Total } & 5074 & 3450 & & 1624 & 68.00 & 32.00 \\
\hline & \multicolumn{2}{|c|}{$\begin{array}{c}\text { First time } \\
\text { blood donors }\end{array}$} & $(\%)$ & \multicolumn{2}{|c|}{ Repeat blood donors } & $(\%)$ \\
\hline Plasmapheresis (FTO VFN) & \multicolumn{2}{|c|}{-} & - & \multicolumn{2}{|c|}{821} & 100 \\
\hline Whole blood (FTO VFN) & \multicolumn{2}{|c|}{171} & 15.36 & \multicolumn{2}{|c|}{942} & 84.64 \\
\hline Whole blood (Subcentres) & \multicolumn{2}{|c|}{261} & 8.31 & \multicolumn{2}{|c|}{2879} & 91.69 \\
\hline Total & \multicolumn{2}{|c|}{432} & 8.52 & \multicolumn{2}{|c|}{4642} & 91.48 \\
\hline
\end{tabular}


Table 2. Analytical sensitivity and reported window periods of assays (95\% confidence interval) (Abbott Laboratories, Ltd., Diagnostics Division, Czech Republic, Roche, Ltd., Molecular Diagnostics, Czech Republic)

\begin{tabular}{llcc}
\hline & \multicolumn{1}{c}{ Method } & $\begin{array}{c}\text { Analytical } \\
\text { sensitivity }\end{array}$ & $\begin{array}{c}\text { Window } \\
\text { period } \\
\text { (days) }\end{array}$ \\
\hline \multirow{3}{*}{ Abbott CMIA } & $\begin{array}{l}\text { HIV Ag/Ab Combo } \\
\text { (toward p24 antigen) }\end{array}$ & $<50 \mathrm{pg} / \mathrm{ml}$ & 17 \\
\cline { 2 - 4 } & HbsAg & $\leq 0.05 \mathrm{UI} / \mathrm{ml}$ & 42 \\
\cline { 2 - 4 } & Anti-HCV & 50 \\
\hline \multirow{3}{*}{$\begin{array}{l}\text { TaqScreen } \\
\text { MPX Test v1 }\end{array}$} & HIV-1 RNA, group M & $49 \mathrm{IU} / \mathrm{ml}$ & \\
\cline { 2 - 4 } & HIV-1 RNA, group O & $89 \mathrm{copies} / \mathrm{ml}$ & 10 \\
\cline { 2 - 4 } & HBV RNA & $59 \mathrm{copies} / \mathrm{ml}$ & \\
\hline
\end{tabular}

Table 3. Summary of the HBV test results

\begin{tabular}{|c|c|c|c|c|}
\hline & \multicolumn{4}{|c|}{$\begin{array}{l}\text { A: Samples of consecutive blood donors } \\
\text { (5074 samples) }\end{array}$} \\
\hline & \multicolumn{2}{|c|}{$\begin{array}{l}\text { HBsAg reactive } \\
\text { (CMIA) }\end{array}$} & \multicolumn{2}{|c|}{$\begin{array}{c}\text { HBV DNA reactive } \\
\text { (Cobas TaqScreen } \\
\text { MPX Test v1) }\end{array}$} \\
\hline & (samples) & $(\%)$ & (samples) & $(\%)$ \\
\hline Reactive & 4 & 0.08 & $6^{*}$ & - \\
\hline NRL negative & 1 & 0.02 & - & - \\
\hline $\begin{array}{l}\text { NRL indeterminate } \\
\text { (further negative) }\end{array}$ & 2 & 0.04 & - & - \\
\hline \multirow[t]{3}{*}{ NRL positive } & 1 & 0.02 & 1 & 0.02 \\
\hline & \multicolumn{4}{|c|}{ B: Preseroconverted samples (5 samples) } \\
\hline & (samples) & $(\%)$ & (samples) & $(\%)$ \\
\hline Reactive & 0 & - & 0 & - \\
\hline
\end{tabular}

HIV-1 RNA (group M and O) and HIV-2 RNA using Cobas s201 system (Hamilton Microlab Star, Cobas Amplicor, Cobas TaqMan; Roche Molecular Systems, Inc., Branchburg, NJ, USA). In this study, the majority of the samples (98\%) were tested using mini-pools of 6 (MP-NAT), 78 samples were tested in an individual donor NAT regime (ID-NAT). The detection was qualitative without discriminatory tests. The discriminatory tests of positive samples were performed by the NRL using Roche Amplicor HCV test, v2; Roche Amlicor/TaqMan HBV test, v2; and Roche Amlicor/TaqMan HIV test, v2. One negative and five positive controls (HIV-1 M, HIV-1 O, HIV-2, HCV, HBV) were performed in each batch of samples.

Confirmation in the NRL. The positivity of CMIA- and NATreactive samples was further confirmed by the NRL. Based on the pathogen type (HCV, HBV, HIV), the suitable algorithm of confirmatory tests was performed using a combination of different methods (Abbott AxSYM/Architect anti-HCV, HBsAg; Biorad Monolisa anti-HCV v2, HBsAg; Ortho anti-HCV v3; Abbott AxSYM anti-HBc; Roche Amplicor HCV test, v2; Roche Amlicor/ TaqMan HBV test, v2, HCV test v2; Roche Amlicor/TaqMan HIV test, v2; Roche Monitor HBV, Murex EIA anti-HIV1/2, HIV p24; anti-HIV-1/HIV-2 Western blot, etc.).

\section{Results}

In the Group 1 of samples, one pool (6 samples, $0.11 \%$ of tested samples) was found NAT-only reactive (without discriminatory testing), but individual NAT were negative for all samples.

\section{HBV testing}

One sample was $\mathrm{HBs}$ Ag reactive (Abbott CMIA, HBsAg value $>250 \mathrm{~S} / \mathrm{CO}$ ) and also HBV DNA-reactive (ID-NAT) in the Group 1 of samples, the donor (first time donor) was further confirmed HBV positive by the NRL. Another three samples ( $0.06 \%$ of tested samples) were CMIA-only reactive, after re-testing by the NRL was one of them negative, two of them were marked as „indeterminate " and no sample was reactive. Donors with indeterminate results were further retested by the NRL from another sample taken three months after the first indeterminate sample, all with negative results. No sample was Abbott CMIA reactive or ID-NAT reactive in the Group 2 (Table 3).

\section{HCV testing}

Fifteen samples $(0.30 \%$ of tested samples) were CMIAonly reactive in Group 1 . After re-testing by the NRL, eight of them were negative, seven were marked as ,indeterminate“ (sample, which was taken from these donors three months after the indeterminate sample was also negative by the NRL) and no sample was reactive.

One sample was ID NAT-only reactive (CMIA negative) in Group 2, the donor was further confirmed as $\mathrm{HCV}$ positive by the NRL, so we identified one window period case (Table 4).

The sample was from a non-remunerated repeat plasma donor. Because of standard look-back process after the following CMIA reactive donation (discarding products of pre-seroconverted donations from CMIA reactive donors in a defined interval, which were further confirmed by the NRL), all plasma products from that donation (a preseroconverted donation) were discarded. We would like to highlight, that it was a plasmapheresis donor only and therefore plasma was in quarantine. 


\section{HIV testing}

Twelve samples $(0.24 \%$ of tested samples) were CMIAonly reactive in Group 1, ten of them were negative after retesting by the NRL and two were marked as "indeterminate“. Another sample, which was taken from these donors three months after the indeterminate sample was also negative by the NRL (Table 5).

The highest number of CMIA false reactive samples was for anti-HCV (0.30\%), followed by HIVAg/Ab (0.24\%) and HBsAg (0.06\%).

\section{Discussion}

Various types of assays have been developed for use in blood screening over the last decades. In the context of the blood screening, appropriate evaluation is required in selecting the type of assay for each TTI based on critical assay characteristics such as sensitivity and specificity, as well as cost and ease of use. Each screening system has its advantages and limitations that should be taken into consideration when selecting assays (WHO Recommendations, 2009).

Around the world, more than 53 milion units of blood are annually screened by NAT, but despite this widespread adoption of NAT, approximately $40 \%$ of 92 milion of blood donations are still not tested with this technology. For example, blood banks in the USA began using NAT to supplement serology in the late 1990s, at first for HIV and HCV, and later for HBV and West Nile virus. At present time, $100 \%$ of the USA blood supply is screened with NAT for HIV-1, HCV, West Nile Virus, and HBV. In the US, NAT technology based on transcription-mediated amplification is used to screen more than $80 \%$ of the blood supply (Strobl, 2011).

Since the first implementation of NAT in Europe in Germany (1997), over 600 millions of donations have been tested measuring NAT yield for various viruses (HIV-1 0.90, HCV 2.24, HBV 15.2 per milion donations) using Roche assays, Novartis/Chiron assays or „in house systems" with different regime of screening (in most cases NAT in mini-pools of samples). The HCV-RNA screening is the method most often used worldwide (Roth et al., 2012).

Of the central European countries (Romania, Bulgaria, Poland, Cyprus, Czech Republic, Slovenia, Slovakia and Hungary), the NAT method has only been implemented in Slovenia and Poland.

The epidemiological situation is considered satisfactory in this region - during 2009, the incidence of HBV (per 100,000) ranged between 0.4 in Poland and 2.77 in Bulgaria (2.36 in the Czech Republic and 1.15 in the EU), HCV between 0.3 in Romania and Slovenia and 7.99 in the Czech Republic (7.58 in the EU), and HIV between 0.7 in Romania and 2.4 in Slovenia (1.5 in the Czech Republic and
Table 4. Summary of the HCV test results

\begin{tabular}{|c|c|c|c|c|}
\hline & \multicolumn{4}{|c|}{$\begin{array}{l}\text { A: Samples of consecutive blood donors (5074 } \\
\text { samples) }\end{array}$} \\
\hline & \multicolumn{2}{|c|}{$\begin{array}{l}\text { Anti-HCV reactive } \\
\text { (CMIA) }\end{array}$} & \multicolumn{2}{|c|}{$\begin{array}{c}\text { HCV RNA reactive } \\
\text { (Cobas TaqScreen MPX } \\
\text { Test } \mathrm{v} 1 \text { ) }\end{array}$} \\
\hline & (samples) & $(\%)$ & (samples) & $(\%)$ \\
\hline Reactive & 15 & 0.30 & 0 & - \\
\hline NRL negative & 8 & 0.16 & - & - \\
\hline $\begin{array}{l}\text { NRL indeterminate } \\
\text { (further negative) }\end{array}$ & 7 & 0.14 & - & - \\
\hline \multirow[t]{3}{*}{ NRL positive } & 0 & - & - & - \\
\hline & \multicolumn{4}{|c|}{ B: Preseroconverted samples (5 samples) } \\
\hline & (samples) & $(\%)$ & (samples) & $(\%)$ \\
\hline Reactive & 0 & - & $1^{*}$ & 0.02 \\
\hline NRL positive & - & - & 1 & 0.02 \\
\hline
\end{tabular}

*One sample in ID NAT was HCV RNA reactive.

Table 5. Summary of the HIV test results

\begin{tabular}{lcccc}
\hline & \multicolumn{4}{c}{ A: Samples of consecutive blood donors (5074 } \\
samples)
\end{tabular}

5.7 in the EU). The incidence of HIV had been continually increasing in the general population of the Czech Republic during the period between 2004 to 2010 - from 0.7 (72 cases) in 2004 to 1.7 (180 cases) in 2010; however, the incidence of HBV and HCV has decreased over the same period (ECDC, 2009, 2010). Concerning the population of blood donors, there has also been a steady rise of incidence of these three infections from 2008, mainly in the first time donors (Database of IHIS).

In 2010, the incidence among acute HBV cases ranged from 0.13 cases in France to 2.32 in the Czech Republic. Numbers and rates for chronic cases in 2010 showed considerably greater variation, with rates ranging from 1.71 in Slovenia to 15.19 in Norway (ECDC, 2012).

In 2010, 26,678 cases of HCV infection were reported by 26 EU and EEA Member States (Belgium, France, Lichteinstein and Spain did not report); this corresponds to an incidence of 6.93 (6.75 in the Czech Republic) (ECDC, 2012). 
Table 6. Estimated costs of NAT (HIV 1, HIV 2, HCV, HBV) implementation in the Czech Republic

\begin{tabular}{lcccc}
\hline & & \multicolumn{3}{c}{$\begin{array}{c}\text { Estimated price for one testing of } \\
\text { MP-NAT* }\end{array}$} \\
$\begin{array}{lcccc}\text { Average number of } \\
\text { donations per year }\end{array}$ & \multicolumn{2}{c}{ (HIV-1, HIV-2, HBV, HCV) } \\
\cline { 2 - 5 } & 34500 & 69000 & 138000 & 207000 \\
\hline First time donors & 538700 & 1077400 & 2154000 & 3232200 \\
\hline
\end{tabular}

*The prices for testing one sample using MP-NAT are estimated based on the information of suppliers and diagnostics test systems in the Czech Republic (sensitivity of MP-NAT is satisfactory for screening of blood donors including cost \& benefit, ID-NAT is more suitable for individual patient because of different mandatory regime of testing).

In the EU/EEA, 27,116 HIV cases were diagnosed in 2010 and reported by 28 of 30 countries (no data from Austria, Lichtenstein); this corresponds to an incidence of 5.7.

The countries with the highest incidence of HIV in 2010 were Estonia (27.8), Latvia (12.2), Belgium (11.0) and the United Kingdom (10.7). The lowest incidence was reported by Romania (0.7) and Slovakia (0.5). The Czech republic reported 180 cases in 2010; this corresponds to an incidence 1.7 (ECDC, 2012).

Based on the epidemiological data from 2009, reported adverse events concerning blood transfusion, the number of donations and the structure of produced blood components, the risk of TTI per 1 milion donations is estimated to be 7 for HCV, 6 for HBV and between 0.4-0.7 for HIV in the Czech Republic (Turek, 2009). Compared to other European countries before and after implementation of NAT (Laperche, 2005), the estimated risk of HIV transmission in the Czech Republic is very low - after implementation of NAT, the lowest estimated risk per milion donations is in Germany (0.18), and the highest in Italy (1.1). However, the estimated risk for HCV in the Czech Republic still remains high (for comparison, the highest estimated risk before NAT implementation was 3.94 in Spain).

We identified one NAT-only positive (HCV) sample in the Group 2 of donations from repeat donors, which corresponds in an order of magnitude with the estimated risk of HCV transmission in the Czech Republic.

Based on the results of standard serological screening (Abbott CMIA), there was one sample CMIA reactive and confirmed positive (NRL) per 28 thousand donations from repeat blood donors and one sample CMIA reactive and confirmed positive per 430 blood donations from first time blood donors; $38 \%$ of the first time blood donors in our blood centre donated blood just once and therefore there is no available information with regards to their results following the donation and also because of budget limitations we were unable to test them by NAT in this study.
They represent the group with the highest potential risk of TTI (Zou et al., 2008).

Based on present methods for screening of infectious markers and on the actual epidemiological situation in the population of blood donors, we came to the following conclusions regarding a potential NAT implementation into routine blood screening of HBV, HIV and HCV in the Czech Republic:

The risk of occult HBV infections after HBV DNA implementation or transmission of infection in HBV DNAnegative donors still remains (it is possible to decrease it by anti-HBc screening, but there are many transfusion units discarded due to anti-HBc positivity after it) (Comanor and Holland, 2006; Allain and Candotti, 2009; Niederhauser, 2011; Spreafico et al., 2012).

Although the estimated cost of treatment of each HIV positive patient is very high, the implementation of HIV RNA-detection brings the lowest benefit for screening of blood donors (very low incidence, with a short estimated window period).

Implementation of testing for HCV RNA can reduce the estimated serological window period by nearly four times.

The implementation will result in increased costs of the tests (Table 6).

To reduce the risk of TTI we focused on laboratory testing of mandatory tested viral infections in blood donors in our study. It is evident that to improve the safety of blood means not only implementation another laboratory tests, but also undergoing processes such as continuous improvement and implementation of donor selection, administering of plasma after quarantine (plasma in quarantine is released for transfusion purposes after six months, when the analysis of following donor's sample gives negative results), and also effective inactivation procedures (we can use inactivation procedures in routine regime only for plasma and platelets for a clinical use).

For completeness, we mention also autologous donations (made by the intended recipient), despite the fact there are many limitations in using autologous blood products for a clinical use. This is the „safest blood“, because there is no exposure to foreign cellular alloantigens or transfusiontransmissible viral infections. But not every patient who will need transfusion should automatically be considered a safe candidate, e.g. pacients with symptomatic coronary artery disease, uncontrolled hypertension, presence or evidence of a bacterial infection etc. (Rudmann, 2005), and the concept of autologous donation is not suitable for processing in general (e.g. different component processing and use, different selection of pacient/recipient and release of autologous blood components etc.).

In conclusion, in our study, we identified one window period case, ie. a sample being reactive and subsequently confirmed as HCV-RNA positive. Although the benefit from reducing the window period of monitored TTI through the 
NAT implementation is proven in many scientific studies including ours (i.e. identifying HCV NAT-only reactive donors), the decision whether NAT will be implemented in the Czech Republic can be made only by other medical and state authorities (ie. governmental institutions).

Acknowledgements. We would like to thank General University Hospital in Prague and the Charles University in Prague, First Faculty of Medicine for support of our work.

\section{References}

Abbott Laboratories, Ltd., Diagnostics Division, Czech Republic. Allain JP, Candotti D (2009): Diagnostic algorithm for HBV safe transfusion. Blood Transfus. 7, 174-182.

Comanor L, Holland P (2006): Hepatitis B virus blood screening: unfinished agendas. Vox Sang. 9, 1-12. http://dx.doi. org/10.1111/j.1423-0410.2006.00773.x

Database of FTO VFN.

Database of IHIS, [online]. c2012, [cit. 10.8.2012], available from $<$ http://www.uzis.cz/vykazy/archiv-vykazu>

ECDC (European Centre for Disease Prevention and Control/ WHO Regional Office for Europe), Annual epidemiological report Reporting on 2009 surveillance data and 2010 epidemic intelligence data (report), 2012, ISBN: 978-92-9193-321-1, available from <http://www.ecdc. europa.eu/en/publications/publications/1111_sur_annual_epidemiological_report_on_communicable_diseases_in_europe.pdf>

ECDC (European centre for disease prevention and control/WHO Regional Office for Europe), Hepatitis B and C in the EU neighbourhood: prevalence, burden of disease and screening policies (report), ISBN: 978-92-9193-213-9, [online], 2011, [cit. 10.8.2012], available from <http:// www.ecdc.europa.eu/en/publications/Publications/ TER_100914_Hep_B_C\%20_EU_neighbourhood.pdf>

ECDC (European Centre for Disease Prevention and Control/ WHO Regional Office for Europe), Annual epidemiological report Reporting on 2010 surveillance data and 2011 epidemic intelligence data (report), [online], c20052013, [cit. 10.11.2013], available from <http://www. ecdc.europa.eu/en/publications/Publications/AnnualEpidemiological-Report-2012.pdf>

ECDC (European centre for disease prevention and control/WHO Regional Office for Europe), HIV/AIDS surveillance in Europe 2010 (report), ISBN: 978-92-9193-324-2, [online], 2011, [cit. 10.9.2012], available from <http://www.ecdc. europa.eu/en/publications/Publications/111129_SUR_ Annual_HIV_Report.pdf>
EU Directive 2002/98/ES, Appendix IV, 2010, [online], [cit. 25.3.2012], available from <http://eur-lex.europa.eu/>

Laperche S (2005): Blood safety and nucleic acid testing in Europe. Euro Surveill. 10, Issue 2, 01 February 2005, [online], 2005, [cit. 10. 10. 2012], available from <http://www. eurosurveillance.org/ViewArticle. aspx? Articleld=516>

McCullough J (2005): Transfusion Medicine, Elsevier, pp.163-439, pp. 111-130.

NRL (National Reference Laboratory for AIDS), Informations Statistics of HIV/AIDS [online]. 2011, [cit. 10.6.2012], available from <http://www.aids-pomoc.cz/info_statistiky.htm>

Němeček V, Malý M, Beneš Č (2011): Trendy ve výskytu HIV, HCV a HBV v ČR. Transfusion and Hematology Today, October; pp.24-25.

Niederhauser Ch (2011): Reducing the risk of hepatitis B virus transfusion-transmitted infection. J. Blood Med. 2, 91-102. http://dx.doi.org/10.2147/JBM.S12899

Regulation about human blood No. 351/2010, [online]. c2010, [cit. 10.5.2012], available from <http://portal.gov.cz/app/ zakony/zakon.jsp?page $=0 \&$ fulltext $=351 \sim 2 \mathrm{~F} 2010 \& \mathrm{nr}=\&$ part $=\&$ name $=\& \operatorname{rpp}=15 \#$ seznam $>$

Roche, Ltd., Molecular Diagnostics, Czech Republic.

Roth WK, Busch MP, Schuller A et al. (2012): International survey on NAT testing of blood donations: expanding implementation and yield from 1999 to 2009 . Vox Sang. 102, 82-90. http://dx.doi.org/10.1111/j.1423-0410.2011.01506.x

Rudmann SV (2005): Textbook of Blood Banking and Transfusion Medicine; Elsevier, pp. 180-231.

Spreafico M, Foglieni B, Berzuini A, Raffaele I, Guarnori A, Prati D (2012): Low Efficacy of current nucleid acid testing (NAT) assay for the identification of occult HBV infection (OBI) and consequences for safety of blood supply in Italy. Vox Sang 103 (Suppl. 1), 163.

Strobl F (2011): NAT in blood screening around the world, Med Lab Obs, April [online] c; NP Communications, LLC; cit. 11.11.2013; available from <http://www.mlo-online. com/articles/201104/nat-in-blood-screening-aroundthe-world.php>

Turek P (2009): Vyšetřování infekčních markerů v transfuzní službě. Transfusion and Hematology Today, September, pp.17-19.

World Health Organisation (2009): Screening Donated Blood for Transfusion - Transmissible Infections - recommendations; [online]. cWorld Health Organisation 2009; cit. 11.11.2013; available from <http://www.who.int/bloodsafety/ScreeningTTI.pdf $>$

Zou S, Fang CT, Doss RY (2008): A method for estimating incidence rate of infectious diseases among first-time blood donors. Transfusion 48, 1827-1832. http://dx.doi. org/10.1111/j.1537-2995.2008.01750.x 